\title{
Seasonal Growing Environment Affects Quality Characteristics and Postproduction Longevity of Potted Miniature Roses
}

\author{
Titus M. Kyalo ${ }^{1}$ and H. Brent Pemberton ${ }^{2}$ \\ Texas A\&M University Agricultural Research and Extension Center, P.O. Box \\ E, Overton, TX 75684
}

\section{Jayne M. Zajicek ${ }^{3}$ \\ Department of Horticultural Science, Texas A\&M University, College Station, TX 77843}

\begin{abstract}
Additional index words. season, photoperiod, temperature, plant height, flower longevity, simulated shipping, shelf life, Rosa
\end{abstract}

\begin{abstract}
To assess the effects of summer-like [high-temperature long-day (HTLD)] vs. winter-like [low-temperature short-day (LTSD)] growing conditions on production quality and postproduction longevity of potted miniature roses, plants of Rosa L. 'Meirutral' and 'Meijikatar' were grown in growth chambers using a short-cycle production schedule (potted liners grown until root establishment, pinched, and flowered). Plants grown under the HTLD environment [30C day/21C night plus $725 \mu \mathrm{mol} \cdot \mathrm{m}^{-2} \cdot \mathrm{s}^{-1}$ photosynthetic photon flux (PPF) for 14 hours per day] had more flowering shoots than those grown under the

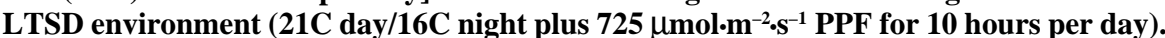
The difference is attributable to fewer blind shoots (shoots with aborted growing terminals) under HTLD, because plants in both environments had the same total number of shoots at flowering. Plants in the HTLD chamber also flowered faster, were shorter, and had smaller and lighter-colored flowers than plants in the LTSD chamber. In addition, plants under HTLD exhibited greater poststorage floral longevity and whole-plant shelf life than plants grown under LTSD conditions, regardless of cultivar, simulated shipping (storage) treatment (4 days at 16C), or stage of floral development at harvest. These results suggest benefits from summer production of potted miniature rose plants and the possibility of using a higher-temperature forcing regimen than is normally recommended for winter production.
\end{abstract}

Increased light intensity and photoperiod result in increased flower production due to an increase in the number of flowering shoots in miniature potted roses (Mortensen, 1991; Zieslin and Tsujita, 1990). Also, growing temperature has been inversely related to blind or nonflowering shoot formation (Moe, 1971; van den Berg, 1984; Zieslin and Halevy, 1975). However, Mortensen (1991) reported that increasing temperature from 18 to $30 \mathrm{C}$ with an 18-h daylength decreased the number of flowers in 'Meijikatar' potted miniature roses.

Received for publication 22 Mar. 1995. Accepted for publication 14 Aug. 1995. This manuscript includes research supported and conducted by the Texas Agricultural Experiment Station, The Texas A\&M Univ. System. We acknowledge Yoder Brothers, Barberton, Ohio, for supplying pot rose plants and Charles E. Gates, Dept. of Statistics, Texas A\&M Univ., College Station, for statistical consulting. This research was funded in part by the Food and Agricultural Organization of the United Nations. The cost of publishing this paper was defrayed in part by the payment of page charges. Under postal regulations, this paper therefore must be hereby marked advertisement solely to indicate this fact. ${ }^{1}$ Former Graduate Student. Current address: P.O. Box 219, Kitui, Kenya.

${ }^{2}$ Associate Professor; to whom reprint requests should be addressed.

${ }^{3}$ Associate Professor
The flower longevity of 'Baccara' and 'Zorina' cut roses was reduced when the growing temperature was decreased from 24 to $12 \mathrm{C}$ before harvest (Moe, 1975). Fjeld et al. (1994) reported a positive effect of supplemental lighting on the vase life of five cut rose cultivars. Chen (1990) observed poorer flower quality, shorter poststorage floral longevity, and more poststorage leaf chlorosis in winter for greenhouse-grown 'Meirutral' and 'Meijikatar' potted miniature roses when compared to summer-grown plants. Also, Rajapakse and Kelly (1994) reported less lower leaf yellowing after simulated shipping on 'Meijikatar' plants grown in the summer in comparison to plants grown in late spring. We investigated the effects of summer-like [high-temperature longday (HTLD)] and winter-like [low-temperature short-day (LTSD)] production environments on plant growth quality characteristics and postproduction longevity of 'Meirutral' and 'Meijikatar' potted miniature roses.

\section{Materials and Methods}

Liners with four rooted cuttings each of 'Meirutral' and 'Meijikatar' were received (Yoder Brothers, Fort Myers, Fla.) on 8 July 1991. They were potted in $11-\mathrm{cm}(550-\mathrm{ml})$ pots using Fison Sunshine Mix \#1 (Fison Horticulture Co., Vancouver, B.C., Canada) and topdressed with $1.6 \mathrm{~g} 14 \mathrm{~N}-6.2 \mathrm{P}-11.6 \mathrm{~K}$ Osmocote (Grace-Sierra Horticultural Products Co., Milpitas, Calif.) per pot. On 5 Aug., 20 plants of each cultivar were randomly selected and placed into two environmentcontrolled growth chambers (model CMP3023; Conviron, Asheville, N.C.). One growth chamber provided a $30 \mathrm{C}$ day $/ 21 \mathrm{C}$ night cycle with a 14-h photoperiod and the second one provided a $21 \mathrm{C}$ day/16C night cycle with a 10$\mathrm{h}$ photoperiod. These growing environments, referred to as HTLD and LTSD, respectively, were chosen to simulate summer-like (HTLD) and winter-like(LTSD) glasshouse conditions. The photosynthetic photon flux (PPF) was $725 \mu \mathrm{mol} \cdot \mathrm{m}^{-2} \cdot \mathrm{s}^{-1}$ at the plant canopy in both chambers with an input wattage ratio of 3.9 cool-white fluorescent : 1 incandescent. The light intensity was representative of winter glasshouse conditions without shading and also of summer glasshouse conditions when shading is used in conjunction with fan-and-pad cooling for temperature control. The relative humidity varied from $65 \%$ to $85 \%$ from day to night, respectively.

The plants were fertilized with $200 \mathrm{mg} \mathrm{N} /$ liter from Peter's 20N-8.9P-16.6K (GraceSierra Horticultural Products Co.) soluble fertilizer. A two-feed, one-leach watering schedule was used for the duration of the experiment. Plants received a weekly application of chelated $\mathrm{Fe}$ and $\mathrm{Mg}$ at 5 and $10 \mathrm{mg} \cdot \mathrm{liter}^{-1}$, respectively. On 28 Aug., roots were visible at the bottoms of the pots and plants were pruned to $5 \mathrm{~cm}$ above the pot rim and grown to flowering. This constitutes a short-cycle crop production schedule.

Harvest stage was determined by development of at least one open flower per plant. 'Meijikatar' plants grown in HTLD and LTSD were harvested on 23 Sept. and 4 Oct. 1991, respectively. 'Meirutral' plants grown in HTLD and LTSD were harvested on 25 Sept. and 8 Oct., respectively. Morphological quality characteristics measured before postproduction treatments included plant height, flower diameter, number of breaks produced after pruning, number of shoots terminating in one or more flowers (flowering shoots), and total number of flowers (open and buds). The number of shoots with an aborted growing terminal (blind shoots) was calculated by subtracting the number of flowering shoots from the number of breaks produced after pruning.

Before simulated shipping (storage treatment), four flowers each at stages 1 (tight bud, calyx not reflexing), 2 (showing color, calyx reflexing, no petals reflexed), and 3 (full color, petals beginning to reflex, traditional bud stage) were randomly tagged for each treatment (Cushman et al., 1994). Half of the plants then were watered and allowed to drain, placed in paper sleeves, and put into ventilated shipping boxes. The boxed plants were placed into dark controlled-temperature rooms for 4 days at 16 $\pm 1 \mathrm{C}$ and $80 \%$ relative humidity to simulate shipping. After simulated shipping (storage treatment), the plants were placed into an interior evaluation environment maintained at a constant $21 \pm 1 \mathrm{C}$ with cool-white fluorescent lighting, which provided an average of 25 
$\mu \mathrm{mol} \cdot \mathrm{m}^{-2} \cdot \mathrm{s}^{-1}$ at plant canopy height. The plants were subirrigated when necessary during the entire evaluation period. The nonstored plants were placed directly in the interior environment.

During the evaluation phase, development of each individually tagged flower was monitored to determine poststorage floral longevity (floral longevity); it was determined by deducting the day the plants were put into the interior room from the sequential day floral life ended. Floral life was considered ended when the flower abscised or died before opening, petals abscised, or the flower naturally senesced as denoted by petal wilting and drying. Whole-plant shelf life in the interior room also was determined by subtracting the day the plant was put into the interior environment from the day each plant was considered to have ended its shelf life. Shelf life was considered ended when $>50 \%$ of the flowers on a plant had reached the end of floral life. In addition, leaf abscission was estimated within $10 \%$ increments.

The experiment was conducted three times. For the second repetition, liners were received on 9 Oct. 1991 and placed into growth chambers on 24 Oct. 'Meirutral' plants from the HTLD and LTSD chambers were harvested on 28 Nov. and 11 Dec., respectively. 'Meijikatar' plants from the HTLD and LTSD chambers were harvested on 27 Nov. and 8 Dec., respectively. For the third repetition, liners were received on 12 Mar. 1992 and placed into growth chambers on 16 Mar. 1992. 'Meirutral' plants from the HTLD and LTSD chambers were harvested on 2 May and 18 May, respectively, while 'Meijikatar' plants were harvested on 30 Apr. and 16 May, respectively.

Treatments were arranged in factorial combination with the factors of growing environment, cultivar, storage treatment, and beginning flower stage. Morphological data was taken from plants in treatment combinations involving the factors of growing environment and cultivar. Treatments were randomized in a split-plot randomized complete-block (RCB) design. Each level of growing environment (one growth chamber) was a main plot with cultivars as subplots. Each replication was considered a block for the analysis of variance (ANOVA). The 10 plants per environment $x$ cultivar treatment combination, therefore, were considered subsamples.

For floral longevity data, the factors of storage treatment and beginning flower stage were added to the above analysis, giving a split-split-plot RCB design. Main plots were levels of environment, subplots were cultivar $\times$ storage treatment combinations, and subsubplots were levels of beginning flower stage. To ensure independence of measurements, each level of beginning flower stage was to have been chosen on each plant. However, this was not possible, because all stages could not be found on each plant. Four sample flowers, therefore, were tagged for each level of flower stage among the five plants in each growing environment $\times$ cultivar $\times$ storage treatment combination. This procedure necessitated av- eraging the data for each four-factor treatment ages then were used in an ANOVA as for the plant growth data, with each replication constituting a block. The plant shelf life and leaf abscission data were analyzed similarly, except without the factor of beginning flower stage. When needed, means separation was done by Duncan's multiple range test (Steel and Torrie, 1980).

\section{Results}

The number of breaks was not influenced by cultivar or growing environment or their interaction (Table 1). However, plants grown under HTLD had more flowering shoots than those grown under LTSD with a corresponding reduction in the number of blind shoots (Table 1). Also, 'Meirutral' plants developed more flowering shoots than 'Meijikatar' plants, with a corresponding decrease in the number of blind shoots (Table 2). Under HTLD growing conditions, plants developed more flowers per plant than those grown under LTSD conditions (Table 1). However, flowers produced under LTSD had a larger diameter than those from HTLD conditions (Table 1).

Plant height was affected by the cultivar $\times$ growing environment interaction (Table 2). 'Meijikatar' and 'Meirutral' plant height was similar when both cultivars were grown under HTLD; but, when both cultivars were grown under LTSD, 'Meijikatar' plants were significantly taller than 'Meirutral' plants. However, plants of both cultivars were shorter under HTLD conditions than those under LTSD (Table 2).

Plants grown under HTLD reached harvest stage (when each plant had at least one open flower) 2 weeks earlier than LTSD-grown plants, but flowers of LTSD plants developed deeper and better color in all experiments (data not presented).

Plant shelf life was significantly affected by growing environment, storage treatment, and cultivar (Table 3 ). There were no significant interactions. Plants that were grown under HTLD lasted 2.3 days longer than those grown under LTSD conditions. Also, plants that were not stored had 6.8 days longer shelf life than those that were stored. The difference of 2.8 days was still significant when the 4 days for the storage treatment were added to the shelf life of the stored treatment. 'Meijikatar' plants lasted 1.1 days longer than combination for each replication. The aver-

'Meirutral' plants (detailed data not presented).

Poststorage floral longevity also was affected by growing environment. Plants grown under HTLD conditions had 4.4 days longer floral life than plants that were grown under LTSD, regardless of beginning flower stage, storage treatment, or cultivar (Table 3 ). In addition, flower stage 1 lasted 1.3 and 1.4 days longer than stages 2 and 3 , respectively, for the nonstored plants. However, there were no differences in floral longevity among the flower stages when the plants were placed under simulated shipping and there was no difference between cultivars. Leaf abscission after 1 week in the evaluation environment and at the end of shelf life (final abscission rating) was only influenced by cultivar (data not presented). In both cases, 'Meirutral' plants lost fewer leaves than 'Meijikatar'.

\section{Discussion}

Because there was no difference in light quality or intensity between the two environments, the increased flowering on plants in the HTLD environment when compared to those in the LTSD environment was due to either light quantity or temperature or both. Increased flowering as a response to higher light intensity is well-documented for cut rose cultivars, but it can be due to a decrease in flower bud atrophy (blind shoot formation) or an increase in budbreak, resulting in more flowering shoots (Zieslin and Mor, 1990). In contrast, the flowering increase on the miniature rose plants in the HTLD chamber relative to LTSD was completely due to reduced blind shoot formation in the former, since there was no difference in budbreak on plants in the two growing environments. Supplemental lighting increased flowering in 'Meijikatar' and 'Meilarco' potted roses, but the relative contribution of reduced blind shoot formation vs. increased budbreak to the observed flowering increases was not measured (Mortensen, 1991; Zieslin and Tsujita, 1990).

Mortensen (1991) reported an increasing number of shoots on 'Meijikatar' plants with increasing PPF. However, the light intensity used in our study was about five times higher than the highest intensity used by Mortensen (1991). The light intensity used in the LTSD chamber must have been high enough for maximum budbreak, since the increased light exposure in the HTLD chamber did not increase budbreak.

Table 1. Effect of growing environment (Environ.) on plant growth and flowering characteristics of 'Meirutral' and 'Meijikatar' roses.

\begin{tabular}{|c|c|c|c|c|c|}
\hline $\begin{array}{l}\text { Growing } \\
\text { environment }\end{array}$ & $\begin{array}{c}\text { Breaks } \\
\text { (no.) }\end{array}$ & $\begin{array}{c}\text { Flowering } \\
\text { shoots } \\
\text { (no.) }\end{array}$ & $\begin{array}{c}\text { Blind } \\
\text { shoots } \\
\text { (no.) }\end{array}$ & $\begin{array}{c}\text { Flowers/ } \\
\text { plant } \\
\text { (no.) }\end{array}$ & $\begin{array}{c}\begin{array}{c}\text { Flower } \\
\text { diam } \\
(\mathrm{mm})\end{array} \\
\end{array}$ \\
\hline$\overline{\text { HTLD }}^{2}$ & $16.1 \mathrm{a}^{\mathrm{y}}$ & $13.2 \mathrm{a}$ & $2.9 \mathrm{~b}$ & $14.3 \mathrm{a}$ & $29 \mathrm{~b}$ \\
\hline $\operatorname{LTSD}^{z}$ & $15.5 \mathrm{a}$ & $8.8 \mathrm{~b}$ & $6.7 \mathrm{a}$ & $10.8 \mathrm{~b}$ & $43 \mathrm{a}$ \\
\hline \multicolumn{6}{|l|}{ Significance } \\
\hline Environ. & NS & $* *$ & $*$ & $*$ & $* *$ \\
\hline Cultivar (cv) & NS & $* *$ & $*$ & NS & NS \\
\hline $\mathrm{cv} \times$ Environ & NS & NS & NS & NS & NS \\
\hline
\end{tabular}

${ }^{\mathrm{z}} \mathrm{HTLD}=$ high-temperature long day; LTSD $=$ low-temperature short day.

${ }^{y}$ Means in columns significant by $\mathrm{F}$ test, $P \leq 0.05$.

Ns, *, **Nonsignificant or significant at $P \leq 0.05$ or 0.01 , respectively. 
Table 2. Effect of cultivar (cv) and growing environment (Environ.) on number of flowering and blind shoots and on plant height.

\begin{tabular}{|c|c|c|c|c|}
\hline \multirow[b]{3}{*}{ Cultivar } & \multirow{3}{*}{$\begin{array}{c}\text { Flowering } \\
\text { shoots } \\
\text { (no.) }\end{array}$} & \multirow{3}{*}{$\begin{array}{c}\text { Blind } \\
\text { shoots } \\
\text { (no.) }\end{array}$} & \multicolumn{2}{|c|}{ Plant ht $(\mathrm{cm})$} \\
\hline & & & \multicolumn{2}{|c|}{ Environ. } \\
\hline & & & HTLD & LTSD \\
\hline Meirutral & $11.9 \mathrm{a}^{2}$ & $4.2 \mathrm{~b}$ & $10.6 \mathrm{a}(\mathrm{b})$ & $13.6 \mathrm{~b} \mathrm{(a)}$ \\
\hline Meijikatar & $10.1 \mathrm{~b}$ & $5.4 \mathrm{a}$ & $11.3 \mathrm{a}(\mathrm{b})$ & 16.6 a (a) \\
\hline \multicolumn{5}{|l|}{ Significance } \\
\hline Environ. & $* *$ & $*$ & $* *$ & \\
\hline $\mathrm{cv}$ & $* *$ & $* *$ & $* *$ & \\
\hline $\mathrm{cv} \times$ Environ & NS & NS & $*$ & \\
\hline
\end{tabular}

${ }^{\mathrm{z}}$ Means in columns and rows (parentheses) significant by $\mathrm{F}$ test, $P \leq 0.05$.

Ns, ${ }^{*},{ }^{* *}$ Nonsignificant or significant at $P \leq 0.05$ or 0.01 , respectively.

Table 3. Effect of growing environment (Environ.), storage treatment, and beginning flower stage (BFS) on plant shelf life and poststorage floral longevity.

\begin{tabular}{|c|c|c|c|c|c|}
\hline \multirow{3}{*}{$\begin{array}{l}\text { Growing } \\
\text { environment } \\
\text { or storage }\end{array}$} & \multirow{3}{*}{$\begin{array}{c}\text { Plant } \\
\text { shelf life } \\
\text { (days) }\end{array}$} & \multicolumn{4}{|c|}{ Poststorage floral longevity (days) } \\
\hline & & & \multicolumn{3}{|c|}{ BFS } \\
\hline & & & $1^{\mathrm{z}}$ & 2 & 3 \\
\hline \multicolumn{6}{|l|}{ Environ. } \\
\hline HTLD $^{y}$ & $13.5 \mathrm{a}^{\mathrm{x}}$ & $14.3 \mathrm{a}$ & --- & --- & --- \\
\hline LTSD $^{y}$ & $11.2 \mathrm{~b}$ & $9.9 \mathrm{~b}$ & --- & --- & --- \\
\hline \multicolumn{6}{|l|}{ Storage (Stor.) } \\
\hline No & $15.7 \mathrm{a}$ & --- & $16.6 \mathrm{a}^{\mathrm{w}}$ & $15.3 \mathrm{~b}$ & $15.2 \mathrm{~b}$ \\
\hline Yes & $8.9 \mathrm{~b}$ & --- & $9.6 \mathrm{a}$ & $9.4 \mathrm{a}$ & $10.5 \mathrm{a}$ \\
\hline \multicolumn{6}{|l|}{ Significance $^{v}$} \\
\hline Environ. & $* *$ & $*$ & & & \\
\hline Cultivar & $* *$ & NS & & & \\
\hline Stor. & $* *$ & $* *$ & & & \\
\hline BFS & --- & NS & & & \\
\hline BFS $\times$ Stor & --- & $*$ & & & \\
\hline
\end{tabular}

${ }^{2}$ Stage 1 = tight bud, calyx not reflexing; stage 2 = showing color, calyx reflexing, no petals reflexed; stage $3=$ full color, petals beginning to reflex, traditional bud stage.

${ }^{\mathrm{y}} \mathrm{HTLD}=$ high-temperature long day; LTSD = low-temperature short day.

${ }^{\mathrm{x}}$ Means in columns within variables significant by $\mathrm{F}$ test, $P \leq 0.05$.

"Means separation in rows within beginning flower stage by Duncan's multiple range test at $P \leq 0.05$.

${ }^{v}$ No other interactions were significant.

Ns, * *** Nonsignificant or significant at $P \leq 0.05$ or 0.01 , respectively.

Temperature also can influence blind shoot formation. Consistent with the results of our study, cool conditions increase the incidence of blindness in cut roses (Moe, 1971; van den Berg, 1984; Zieslin and Halevy, 1975). In contrast to our study, Mortensen (1991) found that the total number of flowers decreased on 'Meijikatar' plants with increasing temperature from 18 to 30C. However, as noted, the light intensity used in our study was higher than the highest intensity used by Mortensen (1991), who also reported on constant temperature treatments compared to the diurnal cycle of our study. The light levels may not have been high enough to compensate for the higher constant growing temperatures, resulting in the reduced flowering reported by Mortensen (1991). Chandler and Watson (1954) hypothesized that a combination of low light intensity and high temperature could reduce net carbohydrate accumulation and, thus, growth of rose plants.

Floral longevity and plant shelf life were enhanced by the HTLD compared to the LTSD environment, confirming the observations by
Chen (1990) of seasonal effects of greenhouse production on postproduction performance. Rajapakse and Kelly (1994) reported a seasonal difference in leaf yellowing after simulated shipping, but our results indicate a difference in floral longevity and plant shelf life regardless of shipping treatment between plants grown in summer-like vs. winter-like conditions. Rajapakse and Kelly (1994) also reported a negative correlation between leaf carbohydrate content and leaf yellowing in an interior environment after simulated shipping and suggested that carbohydrate status could play a role in postproduction performance of 'Meijikatar' potted miniature roses. Fjeld et al. (1994) suggest that the positive effect of supplemental lighting on cut rose longevity is mediated through the carbohydrate status of the plant. The involvement of preharvest environmental conditions and plant carbohydrate status in postproduction longevity of potted miniature roses needs further investigation.

Our study shows potted miniature rose plants had improved postproduction longevity, more flowers, more compact growth, and quicker flowering when plants were grown under HTLD vs. LTSD conditions. However, under HTLD conditions, the plants produced smaller and lighter-colored flowers than those under the LTSD environment. The proper balance of temperature and light needs to be found for optimizing flower quality under hot summer conditions while maintaining the benefits of summer production. Our results also support the idea that higher growing temperatures than normally used could be beneficial for winter production, as had been suggested by Mortensen (1991), contingent on assessment of postproduction longevity. Our demonstration that such a regimen improves postproduction performance of potted miniature roses suggests that commercial use may be worthwhile.

\section{Literature Cited}

Chandler, E.L. and D.P. Watson. 1954. Contributions of various light intensities to the growth and yield of greenhouse roses. Proc. Amer. Soc. Hort. Sci. 64:441-447.

Chen, L.C. 1990. Growth regulator reversal of simulated high temperature shipping effects on flower senescence and leaf abscission. MS Thesis, Texas A\&M Univ., College Station.

Cushman, L.C., H.B. Pemberton, and J.W. Kelly. 1994. Cultivar, flower stage, silver thiosulfate, and BA interactions affect performance of potted miniature roses. HortScience 29:805-808.

Fjeld, T., H.R. Gislerod, V. Revhaug, and L.M. Mortensen. 1994. Keeping quality of cut roses as affected by high supplementary irradiation. Scientia Hort. 57:157-164.

Moe, R. 1971. Factors affecting flower abortion and malformation in roses. Physiol. Plant. 24:291300.

Moe, R. 1975. The effect of growing temperature on the keeping quality of cut roses. Acta Hort. 41:77-88.

Mortensen, L.M. 1991. Effects of temperature, light and $\mathrm{CO}_{2}$ level on growth and flowering of miniature roses. Norwegian J. Agr. Sci. 5:295-300.

Rajapakse, N.C. and J.W. Kelly. 1994. Influence of spectral filters on growth and postharvest quality of potted miniature roses. Scientia Hort. $56: 245-256$

Steel, G.D. and J.H. Torrie. 1980. Multiple comparisons, p. 172-191. In: Principles and procedures of statistics, a biometrical approach. McGrawHill Book Co., New York.

van den Berg, G.A. 1984. Influence of higher night than day temperatures on the winter production of 'Sonia' roses under Dutch glasshouse conditions. Acta Hort. 148:581-590.

Zieslin, N. and A.H. Halevy. 1975. Flower bud atrophy in 'Baccara' roses. II. The effect of environmental factors. Scientia Hort. 3:383391.

Zieslin, N. and Y. Mor. 1990. Light on roses. A review. Scientia Hort. 43:1-14.

Zieslin, N. and M.J. Tsujita. 1990. Response of miniature roses to supplementary illumination. 1. Light intensity. Scientia Hort. 42:123-131. 